\title{
Matkaopas teoreettiseen ja filosofiseen kasvatustutkimukseen
}

\author{
Katariina Holma ja Kaisu Mälkki (toim. 2011): Tutkimusmatkalla: Metodologia, \\ teoria ja filosofia kasvatustutkimuksessa. Helsinki: Gaudeamus. 210 sivua.
}

TUTKIMUSMATKALLA -kirja on tarkoitettu teoreettisen ja filosofisen kasvatustutkimuksen metodologisia ja tieteenfilosofisia kysymyksiä tarkastelevaksi oppikirjaksi. Lukijaa luotsataan tutkimusmatkalle kolmen osakokonaisuuden kautta. Ensimmäisessä kokonaisuudessa tarkastellaan kasvatustieteellisen tutkimuksen yleisiä metodologiaan ja tieteenfilosofiaan liittyviä kysymyksiä. Toisessa osassa esitellään tutkimusesimerkkejä käsitteiden, argumenttien ja ajatuskokonaisuuksien tutkimusprosesseista. Kolmannessa osassa on esimerkkejä filosofisten, teoreettisten ja empiiristen näkökulmien yhdistämisistä. Kirjan kokoavat loppusanat on laatinut Pauli Siljander. Teoksessa siis kaksi kolmasosaa artikkeleista pyrkii kuvailun kautta havainnollistamaan tutkimusprosesseja, minkä lisäksi sekä teoksen alkuun että loppuun on liitetty kokoavampia katsauksia. Rakenne tulee ymmärretyksi oppikirjan ja opiskelijalähtöisyyden näkökulmasta. Suomenkielistä metodikirjallisuutta alueelta on vähän, joten markkinat teokselle ovat olemassa.

\section{KARTANLUKUOHJEITA}

Teoksen ensimmäisen kokonaisuuden (Juha Varto, Eetu Pikka- rainen, Jouni Peltonen) ja loppuluvun (Pauli Siljander) metodologiset yleiskatsaukset käsittelevät kasvatustutkimuksen yleistä olemusta, tutkimustrendejä ja niissä tapahtuneita muutoksia sekä teoreettis-filosofisen kasvatustutkimuksen ominaispiirteitä.

Kirjan aloittaa Varton opiskelijalukijaa orientoiva yleiskatsaus metodologisiin kysymyksiin. Artikkeli on teoksen käytännönläheisimpiä ja selkokielisimpiä, mistä huolimatta monien käsiteltävien asioiden merkityksen oivaltaminen tapahtunee parhaiten kun lukijalla on jo omakohtaista kokemusta tutkimuksen tekemisestä. Esimerkiksi gradunsa empiirisen osan ja analyysiensa toteutusta vasta suunnitteleva opiskelija ei ehkä tavoita mitä tarkoittaa käytännössä, että "aineisto on vahvempi kuin menetelmä" - tai päinvastoin. Varto ohjaa opiskelijaa erottamaan toisistaan tieteenfilosofisen ja konkreettisen empiirisen tutkimuksen. Kirjoittaja muistuttaa, että filosofinen kirjallisuus liittyy enemmänkin yleissivistykseen eikä anna suoraa vastausta empiiriselle tutkimukselle.

Kirjan metodologisissa yleiskatsauksissa sivutaan toistuvasti tieteellisen tutkimuksen lähtö- kohtia ja tavoitteita keskustellen esimerkiksi tieteellisen tiedon, tieteen ja tutkimustoiminnan välisiä suhteita ja vaikkapa havainnollistamalla teorian käsitteen tulkinnan monimuotoisuutta. Luonnollisesti toisteinen teema artikkeleissa on myös tieteenfilosofian keskeisten käsitteiden tarkastelu eri tasoilla ja eri näkökulmista, jolloin yleisempi historiallis-teoreettis-filosofinen keskustelu linkittyy konkreettisiin tutkimusprosessikuvauksiin. Esimerkiksi Siljander nostaa loppuluvussa kasvatustutkimuksen metodologiset ja tieteenfilosofiset kysymykset historiallis-kulttuurilliseen viitekehykseen. Hän avaa laajempaa keskustelua erityisesti konstruktivistisista epistemologioista, kohdeteoreettisesta pluralismista ja päätyy keskustelemaan kasvatustutkimuksen teoriavajeesta ja pohtimaan kasvatustutkimuksen diversiteettiä integroivia näkökulmia. Lukija voi jälkiviisaasti hakea linkkejä kirjan muihin artikkeleihin.

Itse pidin ensimmäisen kokonaisuuden tekstejä ja lopun kokoavaa artikkelia teoksen antoisimpina osuuksina. Tekstit ovat näennäisen jutustelevia, mutta niissä kussakin on runsaasti opiskelijalle hyödyllisiä ja keskeisiä kannanottoja, ei ehkä erityisesti teoreettis- 
filosofisen tutkimukseen, vaan tutkimuksen tekemiseen yleensä.

\section{MATKAILIJA MAASTOSSA}

Toisen kokonaisuuden artikkeleissa (Ulla Solasaari, Kirsi Marja Saurén, Heidi Hyytinen ja Susanna Hannus) kuvataan erityisesti valitun metodin soveltamista ja kuvataan analyysiprosesseja. Analyysiesimerkit liittyvät hermeneuttisesti painottuneeseen filosofiseen analyysiin, systemaattiseen analyysiin sekä argumentaatioanalyysiin. Yleensä lukija saa tietoa tutkimusprosessista tutkimusraportin muodossa, jolloin korostuu se, että tutkimusraportti on jälkikäteen tehty looginen rekonstruktio itse tutkimusprosessista. Kaikkiin luonnollisiin tutkimusprosesseihin sisältyy kuitenkin paljon epäjatkuvuutta ja ennakoimattomuutta (vaiheita, muutoksia, yllätyksiä, käänteitä, tarkennuksia, täsmennyksiä, jne.). Artikkelit kuvaavat virkistävästi kokijansa äänellä näitä epäjatkuvuuksia ja niiden ratkaisuyrityksiä. Omakohtaiset kuvaukset tutkimusaiheen valinnasta ja rajautumisesta avaavat lukijalle näkökulman yleensä näkymättömäksi jääviin tutkimuksen tekemisen vaiheisiin. Onhan aiheenvalinta yksi haastavimmista ja tuskastuttavimmista vaiheista tutkimuksen tekemisessä. Omakohtaisten tutkimusprosessikuvausten yhteyteen on sisällytetty mukavasti myös metodologista ja metodista perustietoa ja ohjeistusta.

Kolmannen kokonaisuuden artikkeleissa (Katariina Holma, Kaisu Mälkki, Anniina Leiviskä ja Aini Oravakangas) tavoitteena on kuvata filosofin tai teoreetikon ajattelun tutkimista. Siinä missä edellisessä kokonaisuudessa painottui analyysimenetelmien toteuttamisen kuvaus näissä artikkeleissa kuvataan kohdettaan varten räätälöityjä tutkimusprosesseja esimerkkeinä filosofinen kasvatustutkimus, teorian rekonstruktio, teorian kehittely ja käsitteen tutkimus. Kuvaukset ovat konkreettisuudessaan valaisevia ja innostavia. Esimerkiksi Holma kuvaa tutkimusesimerkissään antoisasti tutkijan yllättävää oivallusta filosofisessa keskustelussa havaitsemastaan tieteenfilosofisesta realismin ja konstruktivismin ristiriidasta, havainnollistaa ja dokumentoi ristiriitaa sekä tutkimuskysymyksensä muotoutumista tämän havainnon pohjalta.

\section{PÄÄSTIINKÖ PERILLE?}

Opettamisen, kuin myös oppikirjan, perusongelma on kuinka yhdistää teoriaa ja käytäntöä. Tämänkin teoksen yhteydessä joutuu pohtimaan sitä miten yleinen metodologinen keskustelu ja yksittäiset tapauskuvaukset palvelevat ymmärryksen rakentumista. Ensilukemalla teos vaikuttaa hiukan sisäänlämpiävältä.

Sisäänlämpiävyys liittynee osaltaan siihen, että lukijan täytyy lukiessaan muistaa teoksen rajatut näkökulmat. Yleisten metodikirjojen joukossa teoreettisen ja filosofisen tutkimuksen, ja erityisesti kasvatustutkimuksen, metodikirja on harvinaisuus. Pienenä nyanssina voi todeta, että yleisten metodikirjojen runsaan tarjonnan keskellä jotkut pienehkötkin harvinaiset tekstit nousevat arvoonsa. Tällainen esimerkki on Juhani Jussilan, Kaisu Montosen ja Kari E. Nurmen artikkeli systemaattisesta analyysista vuodelta 1989, johon runsaasti viitattaan tässäkin teoksessa.

Teos haastaa monin tavoin lukijaa myös itse pohtimaan ja jäsentämään ilmiöitä kirjoittajien keskinäisten synergioiden avulla. Yleinen metodologinen ja tieteenfilosofinen keskustelu teoksessa tarjoaa runsaasti mahdollisuuksia syventää näkemyksiä ilmiöistä, eritellä niitä ja tehdä omia synteesejä. Oppikirjaluonteen huomioiden synergioiden tunnistettavuutta olisi voinut lisätä korostamalla intertekstuaalisuutta ja näin artikkeleiden keskinäistä keskustelevuutta.

Tarkemmin teosta ja tekstejä analysoiden teoksesta löytyy moninaisia kerroksia ja mahdollisuuksia erilaisten teemojen käsittelyyn. Ongelmaksi saattaa muodostua paikoitellen ymmärrettävyys sekä lukijalta vaadittavien taustietojen ja omatoimisen työstämisen laatu. Niinpä teos sopisi hyvin oheislukemistoksi seminaariin tai luentosarjaan, jossa voidaan tarkastella syvällisemmin ja vuorovaikutteisesti valikoituja kysymyksiä.

Merja Ikonen-Varila 